\title{
Parti Politikası ve Avrupa Birliği Gündemi: Siyasi Rekabet, İdeoloji ve Kimlik Siyasetia
}

\author{
Önder Canveren ${ }^{\mathrm{b}, \mathrm{c}}$, Müge Aknur ${ }^{\mathrm{d}}$
}

\section{Özet}

Aday ülkelerin Avrupa Birliği'ne (AB) katılım sürecinde siyasi partiler önemli roller oynamaktadır. Hem ulusal hem de $\mathrm{AB}$ düzeyindeki parti pozisyonları, entegrasyonun ve aday ülke- $A B$ ilişkilerinin içerik, yön ve dinamiği üzerinde doğrudan bir etkiye sahiptir. Bu nedenle Türkçe literatürde, $A B$ gündemine ilişkin parti pozisyonlarının sistematik bir şekilde yeniden değerlendirilmesi gerekmektedir. $\mathrm{Bu}$ makale, $\mathrm{AB}$ gündemine ilişkin parti pozisyonları ve bu pozisyonların altında yatan sebepler için nedensel açıklamaya imkân sağlayan teorik ve metodolojik yeni bir çerçeve sunmaktadır. Bu çerçeve, parti politikasının temel parametreleri olan siyasi rekabet, ideoloji ve kimlik siyaseti modelleri üzerinden Avrupalılaşma literatürünü irdeleyerek geliştirilmiştir. Çalışma, alternatif parti pozisyonlarını (Avrupa taraftarlığı, yumuşak Avrupa karşıtlığı ve sert Avrupa karşıtlığı) analiz etmek ve karşılaştırmak amacıyla sekiz alternatif hipotez önermektedir.
Anahtar Kelimeler

Avrupa Birliği

Avrupalılaşma

Parti Politikası

Siyasi Partiler

Makale Hakkında

Geliş Tarihi: 05.04.2019

Kabul Tarihi: 25.12.2020

Doi: 10.18026/cbayarsos.549994

\section{Party Politics and the European Union Agenda: Political Competition, Ideology and Identity Politics}

\begin{abstract}
Political parties play significant roles in the European Union (EU) accession process of candidate countries. Party positions at both domestic and the EU levels have a direct impact on the dynamics, direction, and the content of the integration as well as the candidate country's relations with the EU. Therefore, a systemic re-evaluation of the party positions on the EU agenda would contibute to Turkish literature. This article designed a theoretical and methodological framework for the analysis of party positions on the EU agenda for causal explanation underlying these positions. This framework which is developed by reviewing Europeanization literature, as the main parameters of party politics focuses on political competition, ideology and identity politics models. The framework developed eight alternative hypotheses to analyze and compare alternative party positions (pro-European, soft-Eurosceptic, and hard-Eurosceptic).
\end{abstract}

Keywords

European Union

Europeanization

Party Politics

Political Parties

About Article

Received: 05.04.2019

Accepted: 25.12.2020

Doi: 10.18026/cbayarsos.549994

\footnotetext{
a İlk yazarın 2214-A Yurt Dışı Doktora Sırası Araştırma Burs Programı (Belgrad Üniversitesi Siyasi Bilimler Fakültesi) ve 2211-A Genel Yurt İçi Doktora Burs Programı kapsamında, TÜBİTAK tarafından desteklenen doktora tezine dayanarak tercüme edilmiş, revizyonlar gerçekleştirilmiş ve iki yeni hipotez eklenmiştir.

b İletişim Yazarı: onder.canveren@gmail.com

c Araş. Gör. Dr., Dokuz Eylül Üniversitesi, İşletme Fakültesi, Uluslararası İlişkiler Bölümü, ORCID: 0000-0002-5352-7573

d Doç. Dr., Dokuz Eylül Üniversitesi, İşletme Fakültesi, Uluslararası İlişkiler Bölümü, ORCID: 0000-0002-1407-7047
} 


\section{Giriş}

İki büyük dünya savaşının yıkıcı etkisinden sonra Avrupa kıtasında barış ve refahın yeniden inşası için kurulan Avrupa Birliği (AB), yıllar içerisinde üye sayısını arttırarak genişlemiştir. Soğuk Savaş'in sona ermesi ile gerçekleşen rejim değişiklikleri sonrasında eski Doğu Bloğu ülkeleri AB'nin genişleme gündemine dâhil edilmiştir. 2013 yılında gerçekleşen son genişleme ile Hirvatistan 28. AB üyesi olmuştur. Soğuk Savaş'ın bitmesiyle Orta ve Doğu Avrupa'daki ülkeler, $\mathrm{AB}$ çıpası ile ekonomik ve siyasi liberalleşme sürecine girmiştir. Üyelik ödülüne dayanan diş teşvik modeli yoluyla Birlik bu ülkelerin siyasi, ekonomik, sosyal ve hukuki dönüşümlerinde önemli roller üstlenmiştir.

Aday ülkelerin yeniden yapılanma ve reform süreci, Avrupalılaşma literatürünün temel çalışma konusudur. Bu amaçla, AB'nin rol ve etkisi, nedensellik ilişkisini temel alan farklı boyutları ve kurumsal düzenlemeleri de içerecek şekilde, literatürde incelenmektedir. Bu incelemelerin önemli bir kısmı, "rasyonel aktör modeli" ile "koşulluluk ilkesine" dayanan "diş teşvik modeli" üzerinden $A B^{\prime}$ 'nin aday ülkelerdeki etkinlik, meşruiyet ve reform sürecine yoğunlaşmıştır (Schimmelfennig, F. ve Sedelmeier, 2004, s. 661). Fakat Avrupalılaşma sürecinde aday ülkelerde farklı dinamikler ve sonuçlar ortaya çıkmıştır. Bu durum literatürde, iç politikaya has gelişmelerin gündeme gelmesine ve aktörlerin sorunsallaştırılmasına neden olmuştur.

$\mathrm{Bu}$ açıdan siyasi partiler, "eşik bekçileri" olarak iç politikanın ve Avrupalılaşma sürecinin temel belirleyicileri olarak karşımıza çıkmaktadır. Öyle ki hem siyasal temsil hem de yasama ve yürütme fonksiyonları nedeniyle siyasi partiler, süreç içerisinde özne görevi görmektedir. Siyasi partiler, ülke üye ise Birlik düzeyinde, aday ise ulusal düzeyde ilişkilere yön vermekte, yasama ve yürütme yetkileri ile hem süreci belirlemekte hem de sonuçlarını doğrudan etkileyebilmektedir. Bu nedenle Avrupalılaşma sürecinin siyasi partilerin tepkileri üzerinden şekillendiğini iddia etmek mümkündür.

$\mathrm{AB}$ gündemine ilişkin parti pozisyonları, siyaset bilimi ve uluslararası ilişkiler disiplinleri için giderek artan ilgi ve araştırma konusu olmuştur. Bu kapsamda zamanla literatür zenginleşmiş ve farklı yaklaşımların dahil edilmesi ile sofistike bir hal almıştır. Uluslararası literatürde ortaya çıan değişim ve dönüşümler, konunun Türkçe literatürde yeniden ve daha sistematik incelenmesine olan ihtiyacı arttırmıştır. Türkiye'deki literatürde Avrupalılaşma bağlamında siyasi partileri inceleyen sınırlı sayıdaki çalışmalarda aşırı sağ (Öner, 2014; Yıldırım, 2017), Türkiye örneği (Tezcan ve Aras, 2015) ve siyasi partilerin Avrupalılaşması (Arısoy ve Gül, 2011) üzerine analizler yapılmıştır.

$\mathrm{Bu}$ tespit ve gözlemler çerçevesinde bu makalede, $A B$ gündemi üzerinden siyasi partilerin aldıkları pozisyonlara ( $\mathrm{AB}, \mathrm{AB}$ entegrasyonu, $\mathrm{AB}$ üyeliği ve Avrupalılaşma gibi pozisyonlara) ve bu pozisyonların altında yatan muhtemel nedenlere ilişkin bir tasarım geliştirilmiştir. $A B$ üyeliği ve Avrupalılaşmaya ilişkin tasarım, aday ve potansiyel aday ülke örnekleri; $A B$ ve $A B$ entegrasyonuna ilişkin tasarım ise hem üye hem de (potansiyel) aday ülke örnekleri için kurgulanmıştır. Evren içerisindeki tüm siyasi partiler $\mathrm{AB}$ gündemi açısından belirleyici olmadığından; çerçeve, yasama ve yürütme erklerinde hak ve sorumlulukları olan ve mecliste temsil edilen partiler ile sınırlandırılmıştır. 
$\mathrm{Bu}$ amaçla, Avrupalılaşma literatürünün geniş bir taramasına dayanarak siyasi rekabet, ideoloji ve kimlik siyaseti perspektifleri üzerinden bir modelleme geliştirilerek farklı parti pozisyonlarının (Avrupa taraftarlığı, yumuşak Avrupa karşıtlığı ve sert Avrupa karşıtlığı) nedensellik analizinde kullanılabilecek ve partiler-arası mukayeseli çalışmalara imkân sağlayacak olan sekiz hipotez geliştirilmiştir.

Makale dört bölümden oluşmaktadır. İlk bölümde, Avrupalılaşma ve koşulluluğun kavramsal ve teorik çerçevesi detaylandırılmıştır. İkinci bölümde, siyasi partilerin süreç ve ilişkiler ağı içerisindeki rol ve önemi sorgulanmıştır. Üçüncü bölümde ise çalışmaya konu olan siyasi rekabet, ideoloji ve kimlik siyaseti modelleri üzerinden $\mathrm{AB}$ gündemine ilişkin parti pozisyonları için sekiz hipotez geliştirilmiştir. Son bölümde ise parti pozisyonlarının analizine ilişkin araştırma süreci ve farklı veri toplama teknikleri, avantaj ve dezavantajları üzerinden karşılaştırılmıştır.

\section{Avrupalılaşma ve Koşulluluk: Kavramsal ve Kuramsal Çerçeve}

Sovyetler Birliği'nin dağılması ve Berlin Duvarı'nın yıkılması, iki kutuplu dünya düzeninin "Batı zaferi" ile sonlanmasına yol açmıştır. Bu zafer, ilk ve en belirgin haliyle eski Doğu bloğu ülkelerinin iç politika ve rejim dinamiklerinde ortaya çıkmıştır. Orta ve Doğu Avrupa'daki tek parti/tek adam rejimleri yıkılmış, özgür ve adil seçimleri demokratikleşme ve liberalleşme adımları takip etmiştir. Schimmelfennig ve Scholtz'e (2008, ss. 187-215) göre AB bu dönemde, genişleme politikaları üzerinden ülkelerin siyasal değişim ve toplumsal dönüşüm süreçlerine dâhil olmuş ve bir "çıpa" görevi görmüştür. Üyelik için şart koşulan Kopenhag Kriterlerinde sıralanan siyasi, ekonomik ve topluluk mevzuatına ilişkin reformlar aracığıyla $A B$, diş teşvik modelini hayata geçirmiştir.

Önceleri $\mathrm{AB}$ düzeyinde ve derinleşme gündemini merkeze alan akademik çalışmalar, Kopenhag Kriterleri'nin ilan edilmesiyle ve genişleme dalgalarına odaklanarak çeşitlenmiştir. AB'nin, aday ülkelerin politik ve ekonomik liberalleşme sürecindeki rolünü açıklamak için bu sürecin nedenlerini; işleyiş, mekanizma ve sonuçlarını irdeleyen çalışmalar ortaya çıkmıştır. Olsen (2002, ss. 921-952) Avrupalılaşma kavramını Birlik düzeyindeki politikaların (I) aday ülkelerin iç politikalarına etkileri, (II) ortaya çıkan yeni fırsat ve kısıtlamalar ve (III) ulusal politikalara ne şekilde yansıdığını anlama ve açıklama için kullanmıştır.

İç ve dış politikanın birbiri içerisinde örüntülendiği bu karmaşık ilişkiler ağının şemsiyesi konumundaki "Avrupalılaşma" kavramı için literatürde farklı tanımlar ortaya çıkmıştır. Avrupalılaşma kavramını; Mjoset (1997, s. 1) "Avrupa etkisinin, özellikle Avrupa kurumsal modellerinin orijinal kaynaklarının dışındaki alanlara yayılması"; Börzel (1999, s. 574) "Ulusal politika alanlarının, giderek Avrupa düzeyinde oluşturulan politikalara tabii olduğu süreç"; Cowles, Caporaso ve Risse (2001, s. 3) ise, "Avrupa düzeyinde farklı yönetişim yapılarının, diğer bir deyişle, aktörler arasındaki etkileşimi resmileştiren ve sorunların çözümünü sağlayan siyasi, hukuki ve sosyal kurumların ve yaptırım gücüne sahip kuralların oluşturulmasına yönelik uzmanlaşmış politika ă̆larının ortaya çıkması ve gelişimi" olarak tanımlamaktadır.

Olsen (2002, ss. 923-924) Avrupalılaşma kavramının beş farklı kullanım alanını: (I) Avrupa sınırlarındaki değişim (genişleme), (II) Avrupa düzeyinde kurumsallaşma, (III) AB 
kurumlarının ulusal ve ulus-altı yönetişim sistemlerine nüfuz etmesi, (IV) Avrupa siyasi örgütlenmesi ve yönetişimin Avrupa'nın ötesine ihraç edilmesi (V) ve güçlü bir Avrupa'nın inşasına yönelik bir siyasi bütünleşme projesi, olarak sıralamaktadır. Aday ve üçüncü ülkeleri merkeze alan bir başka tanımda Radaelli (2003, s. 30) Avrupalılaşmayı: "Ilk olarak $A B$ kararlarında tanımlanan ve sağlamlaştırılan, daha sonra iç söylemlere, kimliklere, siyasi yapı ve kamu politikalarına dâhil edilen resmi ve gayri-resmi kural, prosedür, politika paradigmaları, stiller, bir işi yapma biçimi ile ortak inanç ve normların (I) yapılandırılması, (II) yayılması (III) ve kurumsallaşması süreci" olarak tanımlamaktadır.

Teorik literatürün tarihsel gelişimini inceleyen Bölükbaşı vd. (2011, ss. 79-82) süreci üç kuşağa ayırmaktadır. (I) Avrupa Topluluğu dönemine denk gelen ilk kuşaktaki çalışmalar, ülkelerin bütünleşme safhalarına ve Birlik düzeyindeki kurumsal yapılanmaya yoğunlaşmıştır. Bu dönemde İşlevselcilik (Functionalism), İşlemselcilik (Transactionalism), Hükümetlerarasıcılık (Intergovernmentalism) gibi klasik bütünleşme teorileri ön plana çıkmıştır. (II) Ortak Pazar'ın kurulması (1986) ile başlayan ikinci kuşak analizler, farklı yönetişim modellerine dayanarak AB'nin nasıl bir aktör olduğu sorunsalı ile ilgilenmiştir. (III) Kopenhag Kriterleri sonrasındaki genişleme dalgalarını kapsayan üçüncü kuşak çalışmalar ise, Avrupalılaşma kavramı üzerinden aday ülkeleri analizlerin merkezine almıştır. Bu son kuşak çalışmalar; AB'nin, aday ülkelerin iç politikalarında değişimi nasıl sağladığını sorunsallaştırmıştır. Aday ülkelerdeki değişim ve dönüşümü açıklamak için literatürde üç alternatif model yer almaktadır:

a. Tarihsel Kurumsalcı Model: Bir ülkedeki değişim ve dönüşümü tarihsel sürecin bir çıktısı olarak görmekte ve tarihsel faktörlerin bu noktada belirleyici roller üstlendiğini iddia etmektedir. Modele göre, özellikle krizler ve tarihsel dönüm noktaları, Avrupalılaşma için potansiyeller ve referanslar barındırabilmektedir. Model ayrıca, reform ve kritik kararların tarihsel birikimlerin gölgesinde gerçekleştiğini ve geçmişin yörüngesine bağımlı olduğunu (path dependency) savunmaktadır. Pollack'a (1996, ss. 437-438) göre bu nedenle tarih ve geçmişin mirası, Avrupalılaşma sürecinde önemli rol oynamaktadır.

b. Rasyonel Kurumsalcı Model: Kurallar bütününü ve insan davranışlarını kurum olarak tanımlayan bu model, aktörlerin rasyonelliği varsayımına dayanmaktadır. Pozitivist kuramın temeli olan "rasyonel seçim" teorisine göre aktörler, karşılarına çıkan seçenekler arasında karzarar hesaplamaları yapmaktadır. AB üyeliğinin yaratacağı kazanımlar, süreçteki maliyetlerden fazla olduğundan Avrupalılaşma, sonuç odaklı hareket eden (logic of consequences) aktörler için rasyonel bir tercih olacaktır. Kopenhag Kriterleri (Koşulluluk) çerçevesinde şekillenmiş olan süreç (Avrupalılaşma) ise mekanik şeklinde değerlendirilmektedir. Literatürün önemli isimlerinden Schimmelfennig ve Sedelmeier (2005, ss. 661-679) üyeliğin yaratacağı mutlak fayda, süreç maliyetlerinden fazla olacağından $A B$ reformlarının hayata geçirileceğini varsaymaktadırlar.

c. Sosyolojik İnşacı Model: Kurumların rasyonel olduğu varsayımına karşı çıkmayan, fakat aktör ve davranışlarının aynı zamanda sosyal bir olgu olduğunun altını çizen bu son model, Avrupalılaşma sürecinde kâr-zarar hesaplamalarının yapıldığı sosyal bağlamı ve kimliği öne çıkarmaktadır. Modele göre süreç, aktörlerin öğrenme ve sosyalleşmeleriyle doğrudan ilintilidir. Aktörler, uygunluk mantığı (logic of appropriateness) çerçevesinde, içselleştirilmiş norm ve kurallara bağlı olarak hareket etmektedir (March ve Olsen, 1998, ss. 
951-952). Bu nedenle süreç içerisinde $A B$ ile uyumlu yeni fikir, norm ve kolektif anlayışların ortaya çıkması, içselleştirilmesi ve yaygınlaşması beklenmektedir (Checkel, 1999, ss. 548-554).

Genişleme politikaları, Birliğin en iyi formüle edilmiş ve en güçlü dış politika aracı olarak tanımlanmaktadır (Grabbe, 2002, s. 250). Koşulluluk mekanizmasından dolayı ilişkiler asimetrik bir yapı arz etmektedir. $A B$, süreç içerisinde hem oyun kuran hem de referans kaynağ 1 olan aktör konumundadır. Bu nedenle ikili ilişkiler, hiyerarşik ve tepeden-inme (topdown) bir görünümdedir. Diez'e (2005, s. 630) göre AB, bu nedenlerle sivil, normatif ve aynı zamanda dönüştürücü bir güçtür.

\begin{tabular}{|c|c|c|}
\hline $\begin{array}{c}\text { Etki } \\
\text { Göstergeleri }\end{array}$ & $\begin{array}{c}\mathrm{AB}^{\prime} \text { 'nin üye/aday devlete etkisi } \\
\text { (Top-down dimension) }\end{array}$ & $\begin{array}{c}\text { Üye/aday devletin } \\
\text { AB'ye Etkisi } \\
\text { (Bottom-up dimension) }\end{array}$ \\
\hline $\begin{array}{l}\text { Kurumsal } \\
\text { Uyum }\end{array}$ & $\begin{array}{l}\text { Bürokratik yeniden yapılanma: kurumlar } \\
\text { arası çatışma/iş-birliği/güç değişimi, yeni } \\
\text { birimlerin kurulması }\end{array}$ & Kurumsal etki \\
\hline Siyasi Uyum & $\begin{array}{l}\text { Karar vericilerin } A^{\prime} B^{\prime} \text { e bakışı: seçkin } \\
\text { Avrupalılaşması } \\
\text { Söylemde değişim } \\
\text { Kamuoyu desteği } \\
\text { Çıkarda değişim } \\
\text { Kimlikte değişim }\end{array}$ & $\begin{array}{l}\text { Gündem oluşturma ve } \\
\text { ilgili politikayı etkileme }\end{array}$ \\
\hline Mekanizmalar & $\begin{array}{l}\text { Sosyalizasyon } \\
\text { Koşulluluk ilkesi } \\
\text { Uyum baskısı }\end{array}$ & \\
\hline $\begin{array}{l}\text { Kolaylaştırıcı } \\
\text { Etkenler }\end{array}$ & $\begin{array}{l}\text { Hükümetin } \mathrm{AB}^{\prime} \text { ye bakışı ( } \mathrm{AB} \text { üyeliği için s } \\
\text { hükümetin koalisyon mu, çoğunluk hükü } \\
\text { Avrupalılaşmaya uygun siyasi kültür } \\
\text { Siyasi aktörler arasında uzlaşı } \\
\text { Tarafların birbirleri hakkındaki algısı: gü } \\
\text { varlığı }\end{array}$ & $\begin{array}{l}\text { iradenin yerleşmiş olması, } \\
\text { mi olduğu) } \\
\text { lirlik ve iletişim zemininin }\end{array}$ \\
\hline
\end{tabular}

Şekil 1. Etki göstergeleri bakımından Avrupalılaşma kavramı

Kaynak: Yazgan, 2012, s. 131.

Etki göstergeleri bakımından Avrupalılaşma kavramı incelendiğinde (Şekil-1) elitlerin AB'ye bakışı, kamuoyu desteği ile kimlik ve çıkarda değişim, kritik önemdeki siyasi uyumun belirleyicileri olarak sıralanmaktadır. Ayrıca iktidar partilerinin AB üyeliğine bakışı, Avrupalılaşmaya uygun siyasi bir kültürün varlığı ve son olarak aktörler arası uzlaşı, Avrupalılaşma sürecini kolaylaştıran faktörler olarak karşımıza çıkmaktadır. Değişen ve sofistike hale gelen literatürü gözden geçiren Schimmelfennig ve Sedelmeier (2004, ss. 661679), Avrupalılaşma sürecini etkileyen ve birbiri içerisinde örtülenmiş olan iç ve diş faktörleri şu şekilde sıralamaktadır:

a. Koşulların Belirginliği (Determinancy of Conditions): Bu faktör, AB üyeliği için talep edilen koşulların belli ve resmi olma durumunu ifade etmektedir. Hem aday ülkenin hem de AB'nin sahip olduğu hak ve sorumluluklar belirgin hale getirilmek yoluyla sürecin güvenirliği arttırılmaktadır. 
b. Ödüllerin Büyüklüğü ve Hızı (Size and Credibility of EU Rewards): Üyelik için gerekli koşulların sağlanması durumunda, $A B$ tarafından verilecek ödülün hız, nitelik ve büyüklüğü Avrupalılaşmanın yönünü, boyutunu ve etkinliğini doğrudan etkilemektedir.

c. Benimseme Maliyetleri (Adoption Cost): Bu faktör, reformların ortaya çıaracağ maliyetlerin, aktörlere olan etkisini ve aktörler arasındaki dağılımını tartışmaya açmaktadır. Yapısal reformların mutlak maliyetleri, bu maliyetlerin iç politikada kimi/nasıl etkileyeceği ve AB'nin süreçteki desteği ile verilecek ödülün nitelik ve büyüklügü süreci etkilemektedir.

d. Veto Odakları/Elitler Arası Yarış (Veto Players/Elite Competition): $\mathrm{Bu}$ faktör, Avrupalılaşma sürecinde güç, etki ve menfaat kaybına uğrayacak olan aktörlerin reformlara karşı çıkması, diğer bir ifadeyle süreci sekteye uğratmasını ifade etmektedir. Veto odaklarının iç politikadaki sayı, güç ve etkilerinin Avrupalılaşmayı engelleyecek düzeyde olmaması beklenmektedir.

e. AB ile Aynîleşme (The Identification with EU): Siyasi elitlerin kendilerini Avrupalı olarak tanımlaması; milli ve devlet kimliklerini, $\mathrm{AB}$ kimliğinin bir parçası olarak görmesi anlamina gelmektedir.

f. İç Rezonans (Domestic Resonance): Bir önceki faktörü tamamlar nitelikteki bu son faktöre göre, ülkedeki norm ve değerler ile $A B^{\prime}$ nin sahip olduğu norm ve değerler arasında yakınsama olması gerekmektedir. Bu yakınsama ikna, öğrenme ve içselleştirmeye kapı aralayarak reformların gerçekleşmesini sağlayacaktır.

\section{Avrupalılaşma Sürecinde Siyasi Partilerin Rolü ve Önemi}

AB-aday ülke ilişkileri gerçekten Avrupalılaşma literatürünün iddia ettiği varsayımlar ve model önermeleri üzerinden mi devam etmektedir? En güçlü dış politika aracı olarak resmedilen ve koşulluluk stratejisine dayanan genişleme politikasında hem süreç hem de sonuçlar dikkate alındığında aday ülkeler arasında neden derin farklılıklar ortaya çıkmaktadır? Diğer bir ifade ile AB, Avrupalılaşma literatürünün iddia ettiği kadar aday ülkelerin iç politikalarında etkili midir? Tüm bu soru ve tartışmalar, literatürün ağırlık merkezi olan Avrupalılaşma ve koşulluluk mekanizmasının ötesine geçerek iç politika dinamiklerine odaklanmayı gerekli kılmaktadır.

Avrupalılaşma sürecinde aday ülkelerde farklı süreçler yaşanmış ve farklı sonuçlar ortaya çıkmıştır. Tarihsel-Kurumsalcı modelin temel savlarının aksine; örneğin Balkan ülkeleri, Orta ve Doğu Avrupa ülkeleri ile aynı zaman diliminde, benzer tehditler altında aynı fırsatlara sahip olmalarına rağmen farklı siyasal sonuçlar ile karşılaşmışlardır. İkinci model açısından bakıldığında ilişkilerin oturtulduğu koşullar aynı iken; aday ülkelerde farklı süreçlerin yaşanması ve farklı sonuçların ortaya çıkması, Rasyonel Kurumsalcı modeli tartışılır hale getirmektedir. Öyle ki AB'yi özne olarak konumlandıran bu yaklaşım, aday ülkelerin iç dinamiklerini edilgen görmektedir.

Bu gözlemler, iç politikaya has dinamiklerin gündeme gelmesine ve artan oranda analizlere dâhil edilmesine neden olmuştur. Bu hususta Yazgan (2012, s. 136) şu tespitleri paylaşmaktadır: "Ülkeler bakımından farklı sonuçların doğması; ülke yapısı ve iç politikadaki gelişmelerin, $A B$ sürecini etkileyen önemli faktörler olduğunu ortaya koymaktadır." Bu kapsamda özellikle karar alıcılar (siyasi elitler) ön plana çıkmaktadır. Siyasi elitlerin, Avrupalılaşma sürecindeki rol ve önemi hususunda Sousa (2006, s. 5) şu tespitleri paylaşmaktadır: 
“Avrupa'nın itici gücü, milli elitler tarafindan yorumlanmakta ve bu yorumlama ile Avrupa algısı, uygun olduğu düşünülen yanıtın türü için belirleyici olmaktadır... Elitler, ulusal düzlemde Avrupa'yı anlamlı yaptıkları ve sosyal olarak inşa ettikleri oranda Avrupa'ya karşılık vermektedir."

Avrupalılaşma, ulusal elitlerin $A B$ ve üyelik koşullarına verdikleri karşılıklar üzerinden şekillenmektedir. Bu nedenle Bulmer ve Lequesne (2002, s. 4) ulusal aktörleri, AB ile ulus devlet arasında eşik bekçisi (gatekeepers) olarak tanımlamaktadır. Avrupalılaşma sürecinde iç politikada dört farklı elit grubu karşımıza çıkmaktadır: (i) hükümet ve bağlı kurumlar (bürokrasi), (ii) ulusal meclisler, (iii) yarg1 ve (iv) son olarak sivil toplum (Hix ve Goetz, 2000, s. 15). Avrupalılaşma süreci, “AB Uyum Paketleri” ile meclis gündemine gelmekte ve yasama, yürütme ve siyasi temsil gibi temel fonksiyonları olan siyasi partiler, talep edilen reformlarda belirleyici rol oynamaktadır. Bu gerekçeyle AB-aday ülke ilişkilerini, siyasi partilerin ana aktör olduğu bir süreç olarak okumak mümkündür.

\section{AB Gündemine İlişkin Alternatif Parti Pozisyonları}

Pozisyon, bir konu ya da aktör hakkında benimsenen genel bakış açısını ifade etmektedir. Kavramı daha genel anlamda, bir aktörün rakiplerine karşı daha fazla menfaate sahip olduğu durumlarda konumlandığı yer olarak tanımlamak mümkündür. Pozisyonun oluşabilmesi için ilgili konunun, öncelikle gündemi meşgul ediyor olması gerekmektedir. Diğer bir ifadeyle aktörler, her durum ve koşulda pozisyon belirlemeyip önem ve önceliğine göre pozisyon alma eğilimi göstermekte (Green-Pedersen ve Walgrave, 2014, ss. 6-9) ve aldıkları pozisyonlar üzerinden siyasi mücadelelerini yürütmektedir. Politik psikolojinin önemli isimlerinden Jon Elster'e (1993, s. 63) göre pozisyon, sadece genel bakış açısını belirlemekle kalmayıp aynı zamanda aktörlerin çıkar tanımlamalarını da etkilemektedir.

Aktörler ana hatlarıyla karşıt (negatif), tarafsız (nötr) ya da tarafgir (pozitif) bir pozisyon alabilmektedir (Gökçe, 2001, s. 25). AB ve Avrupalılaşma ile ilgili tarafgir bir pozisyona sahip olmak Avrupa Taraftarlığı (Pro-Europeanism) olarak tanımlanmaktadır. Kavram; bir aktörün $\mathrm{AB}$, Birlik entegrasyonu ve üyelik konusunda destekleyici bir pozisyon alması durumunu ifade etmektedir. Kopecký ve Mudde (2002, s. 300) bu tarafgirliği Avrupa fikrinin desteklenmesi ya da siyasi olarak AB'nin dayandığı ilkelere bağlılık (pazar ekonomisi, demokrasi, insan hakları vs.) ile açıklamaktadır.

Öte taraftan Avrupa Karşıtlı̆ğ (Euroscepticism) AB, Birlik entegrasyonu ve üyelikle ilgili negatif bir tutum ve karşıt bir pozisyon almayı ifade etmektedir. Taggart (1998, s. 366), kavramı "Avrupa bütünleşmesi fikrine bir bütün olarak ve tartışmasız karşı olmayı da içerisinde barındıran muhalif pozisyon" olarak tanımlamaktadır. Kapsam ve boyutu açısından bu karşıtlı̆̆ın iki biçimi bulunmaktadır: İlki tüm yön ve içeriği reddeden Sert (Hard) Avrupa Karşıtlığı, ikincisi ise kısmi ve koşullu bir muhalif pozisyon olan Yumuşak (Soft) Avrupa Karşıtlığıdır. Yumuşak Avrupa Karşıtlığı, her durum ve koşulda ortaya çıkan bir pozisyon olmayıp görece izafi bir nitelik taşımaktadır. Bu pozisyon özellikle, AB siyasetinin milli çıkarla çatıştı̆̆ zamanlarda ya da seçili konu ve alanlarda (örneğin göç ve dış politika) ortaya çıkmaktadır.

"Tutum" ve "pozisyon", sosyal bilimler için yeni bir çalışma konusu olmayıp; ilk olarak siyaset felsefesinde ortaya çıkmıştır. Siyaset felsefesi, tutum ve pozisyonun referans 
kaynakları ve muhtemel nedenleri üzerinde yoğunlaşmıştır. John Rawls (2009, ss. 15-19), Adalet Teorisi'nde, kolektif boyutun altını çizerek pozisyonu, toplumun farklı kesimlerince savunulan alternatif adalet teorileri içerisinde en çok tercih edilen ve en fazla referans verilen yorum olarak tanımlamıştır. Rasyonalizmin önemli temsilcilerinden Descartes (1991, ss. 1-57) harici bilgi, akıl yürütme ve rasyonel sezgi yoluyla kişilerin bir konu ya da aktör hakkında alg1 ve pozisyon oluşturduğunu iddia etmiştir. İnsan doğasını sorgulayan David Hume (2003, ss. 238-248) ise, çıkar odaklı ahlaki değerlendirmelerin altında, onay (saygı ve övgü) ve reddin (suçlama) olduğunu vurgulamıştır. Son olarak Ahlak Duyusu Teorisinin kuramcısı Francis Hutcheson (1726), bireylerin rasyonel kapasitelerinin aksine, yorum ve değerlendirmelerinde duyguları ile hareket ettiğini savunmuştur.

$\mathrm{Bu}$ felsefi temellerin izdüşümünde Habermas (2001) ve Sjursen (2002), genişleme ve Avrupalılaşma için üç model önermektedir: (I) Maddi kazanımlara (ekonomi, güvenlik vs.) referans veren ve yarar beklentisine dayanan Faydacilı (Pragmatism). (II) "Biz" kolektif anlayışına dayanan ve sorumluluğa referans veren Etik/Siyasal (Ethical/Political) (III) Son olarak toplumsal iyi yaşam düsturundan hareketle ortak (Avrupalı) değerlere referans veren Ahlaki (Moral) Model.

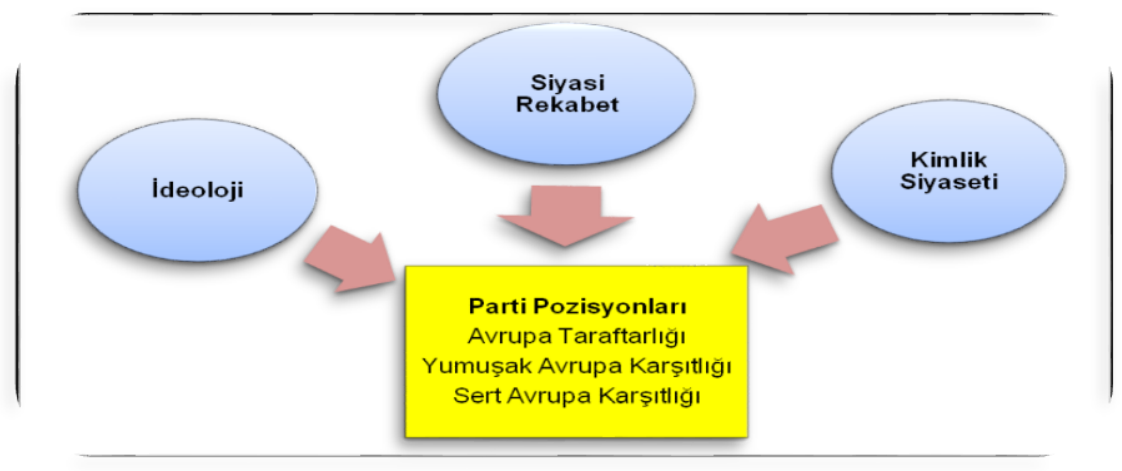

Şekil 2. Model tasarımı

Yukarıda detaylandırdığımız felsefi önermelere ve Habermas ile Sjursen'in çalışmalarına dayanarak bu makalede parti pozisyonlarının analizi için üç model geliştirilmiştir: İdeoloji, Siyasi Rekabet ve Kimlik Siyaseti (Şekil-2). Faydacılık, kar-zarar hesaplamasına dayandığından çalışmanın siyasi rekabet modeline; etik/siyasal yaklaşım ortak değerlere ve kolektif anlayışa vurgu yaptığından çalışmanın kimlik siyaseti modeline ve son olarak ahlaki önerme iyi yaşam kurgusuna ve değerlere vurgu yaptığından çalışmanın ideoloji modeline zemin oluşturmaktadır.

\section{İdeoloji ve Parti Pozisyonlan}

Downs (1957, s. 96) ideolojiyi, iyi toplum idealinin kurgulanan bir imgesi ve böyle bir toplumun inşası için öne sürülen araç olarak tanımlamaktadır. Benzer şekilde Heywood (2012, s. 11), ideolojilerin temelde sistematik ve organize edilmiş görüşler, ideal toplum vizyonu ve siyasi değişim için bir model(ler) önermesi olduğunu vurgulamaktadır.

İdeoloji, normatif ve üretken boyutları nedeniyle siyasi aktörler için vazgeçilmez referans kaynaklarıdır. Siyasi ideolojiler, pozisyon belirlemek için gerekli "bilgi yumağını" sağladığından üretken; savunduğu değerler, siyasi bilgilerle birleşerek belli bir konuda 
düşünce üretme imkânı sunduğundan normatiftir (Martin ve Desmond, 2010, ss. 8-9). Bu nedenlerle ideolojiler, siyasette akıl yürütmeye katkı sağlamakta ve bu sayede aktörlerin tutum ve pozisyonların belirleyebilmektedir (Sniderman vd., 1993, s. 156). İdeolojik hizipleşme ise soyut (tutum) ve somut (davranış) alanı kapsayacak şekilde, temelde değerler arasındaki farklılaşmalardan kaynaklanmaktadır (Billig, 1984, s. 446).

İdeolojik hizipleşme için literatürde farklı siyasi yelpazeler kullanılmaktadır. Doğrusal yelpaze (linear spectrum), ekonomi politikalarını temel almakta ve ideolojileri sağ-sol ana ekseni üzerinden kategorize etmektedir. At nalı yelpazesi (horseshoe spectrum) ise demokratik değerler ile özgürlükler konusundaki pozisyonlarını dikkate alarak ideolojileri ılımlı (moderate) ve aşırı (extreme) ana ekseni üzerinden kategorileştirmektedir. Son yelpaze ise zaman değişkenini dikkate alarak ideolojileri "klasik" ve "modern" olarak ikiye ayırmaktadır.

Doğrusal yelpaze açısından bakıldığında belirli bir konu ya da aktör hakkındaki tutum, pozisyon ve söylem, sağ-sol ayrımının gölgesinde ve ona bağlı olarak ortaya çıkmaktadır (Marks ve Wilson, 2000, s. 434; Marks ve Steenbergen, 2002, s. 889). Bununla beraber parti politikasındaki sağ-sol ayrımı, ülkeler arasında farklılıklar göstermektedir. Bir ülkede ideolojik ayrım ekonomi politiği üzerinden şekillenirken, başka bir ülke örneğinde hizipleşme egemenlik ve bağımsızlık gündemine oturabilmektedir. Bu nedenle klasik sağ-sol ayrımı üzerinden genel geçer bir hipotez geliştirmek mümkün değildir. Her ülkenin parti politikasındaki ideolojik hizipleşmenin köken ve referans noktaları dikkate alınarak $\mathrm{AB}$ gündemine ilişkin aşağıda sıralanmış olan hipotezlerden uygun olanı kullanılabilir (Keulman ve Koós, 2014, ss. 202-203).

a. Düzenleme Modeli (Regulation Model): Avrupa siyasetinde, ekonomi politikaları konusunda daha az devlet müdahalesini ve devlet düzenlemesini savunan sağ ile daha fazla devlet müdahalesini ve düzenlemesini savunan sol partiler arasında tutum ve pozisyon farklılaşması söz konusudur. Üyelik kriterleri, temelde iktisadi liberalleşmeyi ve piyasa ekonomisine geçişi gerekli kıldığından sağ ile sol cenahtaki partiler, farklı pozisyonlar alabilmektedir. Ekonomide devlet müdahalesine karşı çıkıp liberal ekonomiyi savunan sağ partiler doğal olarak AB üyeliğine daha sıcak bakmaktadır:

Hipotez 1a: Să̆ partilerin, sol partilere kıyasla AB gündemine ilişkin (daha) taraftar bir pozisyon almaları beklenmektedir.

b. Hix-Lord Modeli: $A B$ entegrasyonu ve üyelik, ülkelerin ulusal egemenliği ve bağımsızlığını dönüştürdüğünden ve iç işlerine müdahaleye kapı araladığından farklı tepkiler ve parti pozisyonları ortaya çıkmaktadır. Bu bağlamda milliyetçi ve muhafazakâr söylemlerin daha yoğun olduğu sağ partilerin, sol partilere göre daha karşıt ya da kuşkulu bir pozisyon almaları mümkündür:

Hipotez 1b: Sol partilerin, să̆ partilere kıyasla AB gündemine ilişkin (daha) taraftar bir pozisyon almaları beklenmektedir.

c. Hooghe-Marks Modeli: Bir refah projesi olarak AB, gelirin yeniden dağıtılması, sosyal politikalar, işsizlikle mücadele vb. konuları kapsadığından parti pozisyonları sağ-sol 
hizipleşmesinden etkilenebilmektedir. AB'nin sosyal boyutunu önemseyen ve öncülleştiren sol partilerin bu noktada daha tarafgir bir pozisyon almaları mümkündür:

Hipotez 1c: Sol partilerin, să̆ partilere kıyasla $A B$ gündemine ilişkin (daha) taraftar bir pozisyon almaları beklenmektedir.

Avrupa'da partiler arası hizipleşme; devlet inşası, din, sınıf vb. tartışmaların kaynağı olan Reform, Aydınlanma ve Sanayi Devrimi gibi tarihi hadiselerin gölgesinde şekillenmiştir. Berlin Duvarının yıkılması, tarihsel süreçte son kırılmayı yaratmış ve sol ideolojilerin zayıflamasına neden olmuştur. Bu zayıflama ilk olarak eski komünist/sosyalist partilerin dönüşerek demokratikleşmelerine; ikinci olarak da siyasetin klasik sağ-sol ayrımından uzaklaşarak partilerin demokratik değerler ve özgürlüklere ilişkin yeni bir yelpaze üzerinden hizipleşmelerine neden olmuştur (Huber ve Inglehart, 1997, s. 74). Tony Blair'in Birleşik Krallıktaki 'Üçüncü Yol' projesi bu noktada dikkat çekmektedir ki, sağ-sol ayrımına dayanan eski hizipleşme zaman içerisinde 1lımlı-aşırı temelli yeni bir hizipleşmeye evrilmiştir (Weltman ve Billig, 2001, s. 369).

At Nalı Yelpazesi, ilk yıllarından itibaren Birliğin entegrasyon sürecini anlama ve açılamada önemli bir değişken olarak analizlere dahil edilmiştir. Fonksiyonalizmin kurucusu Ernst Bernard Haas (1958, ss. 113-159), AB projesinin ve ilerleyen ylllardaki derinleşmenin, özellikle merkez sağda, merkezde ve kısmen merkez solda yer alan siyasi partilerin ürünü olduğunu vurgulamıştır. AB Parlamentosu'ndaki siyasi grupların dağılımı dikkate alındığında; at nalı yelpazesi tarafından kategorize edilen merkez partilerin, Avrupa entegrasyonunun ardındaki itici güç olduğu gözlemlenmektedir. Buna karşılık- özellikle Fransa, Avusturya ve İtalya başta olmak üzere- üye ülkelerde yükselen aşırı sağın, hem $A B$ projesine hem de $A B$ gündemine artan oranda karşıt bir pozisyon takındıkları gözlemlenmektedir. Bu ikinci yelpaze üzerinden şu hipotezi geliştirmek mümkündür:

2. Hipotez: Ilımlı/merkez (moderate) partilerin, aşırı/uç (extreme) partilere kıyasla AB gündemine ilişkin (daha) taraftar bir pozisyona sahip olmaları beklenmektedir.

Klasik ve modern ayrımı, ideolojilerin ortaya çıkış tarihlerini dikkate alarak sadece zaman değişkenine göre bir kategorileştirmeye gitmiştir. Dünya görüşü ve normatif çatışmaları dikkate almayan bu yelpaze üzerinden bir hipotez geliştirmek mümkün değildir. Öyle ki hizipleşmeye neden olan nokta zaman değişkeni olup, her iki grup da kendi içerisinde oldukça heterojen dağılabilmektedir.

\section{Siyasi Rekabet ve Parti Pozisyonları}

İlk model, ideoloji temelli siyasi hizipleşmenin olduğu ülkelerde parti pozisyonlarını anlama ve açıklamada yararlı iken; ideolojinin görece zayıf olduğu ülke örneklerine ilişkin analizlerde bu model yetersiz kalmaktadır. Öyle ki parti pozisyonlarında ideolojik etkinin olmadığı ülke örnekleri mevcuttur (Real-Dato, Göncz ve Lengyel, 2012, ss. 67-93). Siyasi partiler, pozisyonlarını ideolojilerin aksine daha taktiksel ve faydacı yöntemlerle, ilişkiler ağının kendileri ve seçmenleri için getireceği fayda ve maliyetleri dikkate alarak kurgulayabilir. Bu durumda parti pozisyonları görece esnek, söylemsel ve değişime açık bir karaktere bürünmektedir (Szczerbiak ve Taggart, 2000, s. 19). 
Anthony Downs, 1957 (ss: 135-150) yılında kaleme aldığ 1 An Economic Theory of Democracy başlıklı çalışmasında parti politikasını; partilerin siyasi desteği (oy) maksimize ederek iktidar olmayı amaçladıkları, "rekabete" dayalı bir alan olarak tanımlamaktadır. Downs'a göre en fazla oy alanın iktidar olduğu çok partili rejimlerde siyasetçiler; muhalefette ise iktidar olma amacı güden, eğer iktidarda ise devamına odaklanan rasyonel aktörlerdir. Rekabet temelli bu modele göre siyasi partiler tutum ve pozisyonlarını, bir bütün olarak faydacılık, güç mücadelesi ve politik taktikler üzerinden oluşturmaktadır (Neumayer, 2008, s. 137).

Siyasi rekabet temelli bu ikinci modelin ilk önermesi, hükümeti ve muhalefeti oluşturan partilerin mukayesesine dayanmaktadır. AB gündemi, özellikle seçim dönemlerinde siyasi kampanyaların ve rakip partileri eleştirmenin (hükümet-muhalefet) bir aracı olarak kullanilabilir (Sitter, 2001, s. 24). Muhalefet partileri iktidarın AB hususundaki pozisyonuna karşı bir pozisyon alarak Avrupalılaşma, müzakere süreci ve üyeliği siyasi malzeme konusu yapabilirler. Hükümet ile muhalefet arasındaki farklılaşmanın yönü hususunda bir hipotez oluşturmak mümkün olmamakla beraber genel sav, iktidar partileri ile muhalefet partilerinin karşıt pozisyonlar alabileceği yönündedir:

3. Hipotez: Hükümeti oluşturan partiler ile muhalefeti oluşturan partilerin, AB gündemine ilişkin karşıt pozisyonlara sahip olmaları beklenmektedir.

Seçmenler, aşağıdan yukarıya (bottom up) bir mekanizma ile siyasi partilerin pozisyonlarını belirleyen ana güç olabilir. Bazen seçmen davranışları ve milli hassasiyetler, $\mathrm{AB}$ gündemi ve Avrupalılaşmayı da kapsayacak şekilde seçili konu(lar) üzerinde şekillenebilir (Heath, Jowell ve Curtice, 2001, s. 156). Bu önermeye göre seçmen grupları, hassas oldukları konularda kendileriyle benzer pozisyona sahip olan siyasi partilere oy verme eğilimindedir. Bu nedenle siyasi partiler, söylem ve pozisyonlarını seçmen hassasiyetlerini dikkate alarak kurgulamakta ya da ihtiyaç halinde değiştirebilmektedir.

Yapılan çalışmalar, AB gündeminin artan oranda seçmen davranışlarını etkilediğini ve partiler arası hizipleşmenin nedenleri arasına girdiğini göstermektedir (De Vries, 2010; De Vries vd., 2011; Adams, Ezrow ve Somer-Topcu, 2011, s. 370). Bu noktada özellikle eski komünist ülkelerdeki sosyalist partilerin seçmenlerine hitap edebilmek için zamanla Avrupa taraftarı bir pozisyon alarak tutum değişikliğine gitmeleri örnek verilebilir. Bu gözlemler ışığında şu hipotezi geliştirmek mümkündür:

4. Hipotez: $A B$ gündemine ilişkin parti pozisyonlarının (karşıt veya taraftar), seçmen pozisyonuyla aynı olması beklenmektedir.

Seçmen davranışları üzerinden geliştirilen diğer bir kategorik modelleme, partilerin mevcut politik düzen ve statükoya ilişkin aldıkları pozisyonları sorunsallaştırmasıdır. Bu amaçla siyasi partiler, ana akım (mainstream) partilere karşı protesto (protest) partileri olarak sinıflandırılmaktadır (Van Der Brug, Fennema ve Tillie, 2000; Szczerbiak ve Taggart, 2000, s. 7). Ana akım partiler, rejim taraftarlarını temsil etmekte olup, mevcut sistemi sorgulamaksızın statükoyu devam ettirme üzerine bir siyaset geliştirir. Protesto partileri ise, mevcut düzenden ve bu düzeni temsil eden ana akım partilerden memnun olmayan gruplardan oy alarak düzene "meydan okuyan" revizyonist pozisyonları ile siyaset arenasına çımaktadır. Sağ ve 
sol yelpazenin uçlarında yer alan aşırı partiler ile protesto partileri arasındaki fark, ideolojik pozisyonlarından kaynaklanmaktadır. Her iki grup da sistem karşıtı ve revizyonist olmakla beraber, aşırı partiler pozisyonlarını ideolojik bir söyleme (aşırı sağ ya da aşırı sol) dayandırırken protesto partileri ana söylemlerini ideoloji üzerine oturtmazlar, genelde düzene meydan okumakla meşgullerdir.

Protesto partilerini "düzen karşıtı" olarak tanımlayan Sitter (2001, s. 24), bazı sosyalist ve sağdaki popülistlerin bu kategori içerisinde incelenebileceğini belirtmektedir. Protesto partileri, düzeni eleştirmek veya ana akım partilerden ayrışmak amacıyla AB karşıtlı̆̆ını araçsallaştırılabilirler. Benzer şekilde, bu partiler Avrupa-karşıtı söylemlerini statüko ve elitkarşıtı bir söyleme indirgeyebilirler. Bu kategorileştirmeye dayanarak şu hipotezi geliştirmek mümkündür:

5. Hipotez: Ana akım (mainstream) partilerin, protesto partilerine kıyasla AB gündemine ilişkin (daha) taraftar bir pozisyona sahip olmaları beklenmektedir.

\section{Kimlik Siyaseti ve Parti Pozisyonları}

Milli kimlik, ulus-devlet temelli uluslararası ilişkilerin çağdaş formu olarak Vestfalya Anlaşmasına (1648) dayanan modern devletin toplumsal köklerini oluşturmaktadır. Vestfalya'dan sonra "milletler dünyası"nın temeli olan kimlik, özellikle Fransız İhtilali'ni (1789) takip eden yüzyıllarda milli bir hüviyet alarak diğer alternatiflerin önüne geçmiştir (Billig, 1995). Miller (1995) milli kimliği, tarih ve mekânın ortaklığında bireyleri anlamlı bir düzlemde bir araya getiren ve geniş kitlelerin dâhil olduğu, paylaşılan ortak geçmişin bir öyküsü/yansıması olarak tanımlamaktadır. Çağdaş formuyla milli kimlik, ulusal rejimler için bir varlık ve meşruiyet kaynağ 1 olmakta, Smith'e (1991, s. 184) göre ise ulus-devlet inşa sürecinde siyasi bir proje olarak hayata geçirilmektedir.

Sosyal psikolojinin önemli isimlerinden Tajfel ve Turner (1979, s. 40) "Toplumsal Kimlik Teorisi" başlıklı çalışmalarında gruplar-arası ilişki ve davranışların; algılanan grup statüsü, meşruiyet ve istikrar değişkenlerine bağlı olarak biz ve onların (us vs. them) gölgesinde şekillendiğini iddia etmektedir. Teoriye göre, grup üyeleri (biz), grup dişında kalanlar ya da diğer gruplar (onlar) için ekseriyetle negatif söylemler geliştirmekte, bu yolla kendi imajlarını olumlamaya ve bağlarını güçlendirmeye çalışmaktadır. Bu strateji, grup içi dayanışma ve dinamizmi arttırmakla beraber, ötekileştirme faktörü nedeniyle çatışma ve kriz potansiyellerini de taşımaktadır.

Bu teoriden esinlenerek Helbling vd. (2008, s. 21) kimlik kurgularına dayanarak siyasi partileri ikiye ayırmaktadır: (I) Katı Milliyetçi- Dışlayııı: Aşırı milliyetçi ve yabancı düşmanlığı içeren söylemlerin yoğun olduğu; milli değerler, ulusal bağımsızlık ve self determinasyona vurgu yapan yaklaşım. (II) Çokkültürlü- Kapsayıcı: Kültürel çoğulculuk ve hoşgörü başta olmak üzere barış, eşitlik, insan hakları ve demokrasi gibi daha kapsayıcı değerlere vurgu yapan yaklaşım.

Avrupalılaşma açısından bakıldığında, siyasi partilerin Avrupa kimliği ve AB değerleri ile bir aidiyet ve aynîleşme mi, yoksa bir farklılaşma ve ötekileştirme mi kurduğu sorusu, pozisyon ve politika tercihleri açısından önem arz etmektedir. Aktörlerin kimlik tahayyülleri Avrupalılaşma sürecinde potansiyellerle beraber tehditleri de içerisinde barındırmaktadır. 
Öyle ki kimlik siyaseti, bir bütün olarak milliyetçilik, demokrasi ve egemenlik algısı yoluyla uluslararası iş birliği ve bölgesel entegrasyon gibi konularda partilerin genel kanılarını doğrudan etkileyebilmektedir (Hooghe ve Marks, 2009, ss. 21-22; Sitter, 2001, s. 24). Bu nedenlerle, $\mathrm{AB}$ gündemine ilişkin parti pozisyonları- milliyetçilikten çokkültürlülüğge- kimlik politikasının gölgesinde şekillenebilmektedir. Bu gözlemler ışığında, aşağıdaki hipotezi geliştirmek mümkündür:

6. Hipotez: Çokkültürlü (kapsayıcl) kimlik kurgusuna sahip olan partilerin, katı milliyetçi (ötekileştirici) kimlik kurgusuna sahip partilere kıyasla $A B$ gündemine ilişkin (daha) taraftar bir pozisyona sahip olmaları beklenmektedir.

Kimlik modeline ilişkin bir diğer yaklaşım, siyaset sosyolojisinin önemli isimleri Lipset ve Rokkan (1967) tarafından geliştirilmiştir. Bu yeni kuram, tarihsel süreçte oluşan toplumsal bölünmelere (politik, ekonomik, kültürel vs.) bağlı olarak ortaya çıkan sosyal kimliklerin, parti siyasetinin yapı taşı olduğunu iddia etmektedir. Kurama göre parti pozisyonlarını ve siyasi yönelimleri belirleyen ana değişken toplumsal kökler, diğer bir ifadeyle sosyal kimliklerdir (Marks ve Wilson, 2000, s. 434).

$\mathrm{Bu}$ modele dayanarak siyasi partiler, merkez ve çevre (core vs. periphery) ayrımı üzerinden sınıflandırılmaktadır. Merkez, karar alma gücüne sahip ve iktidar araçlarını elinde bulunduran aktörleri ifade etmekte olup çevre üzerinde asimetrik bir üstünlüğe sahiptir. Siyasetin sosyolojik köklerine dayanan bu merkez-çevre ayrımı, siyasi partilerin AB taraftarı ya da karşıtı pozisyon almalarına neden olabilmektedir. Genel gözlem çevrede yer alan partilerin, merkezde yer alan partilere kıyasla daha karşıt bir pozisyon aldığ1 yönündedir (Pisciotta, 2016, s. 194; Szczerbiak ve Taggart, 2000, s. 5). Buradan hareketle aşağıdaki hipotezi geliştirmek mümkündür:

7. Hipotez: Merkezde (core) yer alan partilerin, çevrede (periphery) yer alan partilere kıyasla AB gündemine ilişkin (daha) taraftar bir pozisyona sahip olmaları beklenmektedir.

Modelin üçüncü önermesi ise siyasi partilerin- etnisite ya da inanç temelinde- toplumsal katmanların hangi cenahını temsil ettiği üzerinedir. Bir partinin toplumsal tabanda çoğunluğu mu yoksa azınlığı mı temsil ettiği sorusu, parti pozisyonlarını ve politikalarını etkileyebilmektedir. İnsan haklarına saygı ve azınlık haklarının korunması, siyasi koşullardan birisi olduğundan; Avrupalılaşma süreci, ülkedeki vatandaşlık rejimini ve kimlik siyasetini azınlıklar lehine yeniden inşa etme/ettirme potansiyeline sahiptir (Keating, 2004, ss. 368-369). $\mathrm{Bu}$ sebeple azınlık partilerinin ekseriyetle $A B$ taraftarı cenahta yer aldığı ve ülkenin Avrupalılaşma sürecini bir bütün olarak desteklediği gözlemlenmektedir (Elias, 2009, s. 2; Hix ve Lord, 1997, s. 27). Diğer taraftan, çoğunluğu temsil eden siyasi partiler, AB ve koşulları nedeniyle ulusal egemenliğin ve toprak bütünlüğünün tehdit edildiği kaygısını paylaşabilir (Dechezelles ve Perottino, 2008, s. 5). Bu tehdit algılaması nedeniyle de Avrupa karşıtı bir pozisyon alabilir. Bu gözlemlere dayanarak şu hipotezi geliştirmek mümkündür:

8. Hipotez: Azınlık partilerinin, AB gündemine ilişkin çoğunluk partilerine kıyasla (daha) taraftar bir pozisyona sahip olmalar beklenmektedir. 


\section{Parti Pozisyonlarının Analizi için Veri Toplama Teknikleri}

Laver ve Hunt (1992), AB gündemine ilişkin parti pozisyonlarının araştırma ve incelemesi için üç teknik önermektedir: (I) parti dokümanlarının analizi, (II) kamuoyu anketleri (III) ve uzman anketi. Milletvekilleri ile mülakat yapılması dördüncü bir yöntem olarak bu listeye eklenebilir. Üç yöntemin de kendi içinde avantaj ve dezavantajlarının olduğunu vurgulayan Ray'a (1999, ss. 284-285) göre yazılı belgelerin analizi (içerik çözümlemesi), genel parti pozisyonlarının belirlenmesi ve altındaki muhtemel nedenlerin derinlemesine incelenmesi için işlevsel olmakla beraber, sübjektif yorumlanma riskini barındırmaktadır. Kamuoyu anketleri, özellikle seçmen- parti mukayesesi yapmak için işlevsel olmasına rağmen, zaman ve örneklem sayısı nedeniyle maliyetlidir. Son olarak diğer tekniklerin sınırlı olduğu durumlarda kullanılabilecek olan uzman anketi, derinlemesine (nedensel) analiz açısından sınırlı veriler sunmaktadır.

Kamuoyu anketi zaman alan maliyetli bir yöntem olması ve öngörülemeyecek zorlukları nedeniyle akademide görece daha az tercih edilmektedir. Buna rağmen özellikle siyasi partilerin talebi üzerine, $\mathrm{AB}$ gündemini de kapsayacak şekilde dış politika hususunda artan oranda kamuoyu yoklamaları yapılmaktadır. Ayrıca kamuoyu anketleri, parti pozisyonlarının seçmen davranışlarıyla şekillendiği varsayımına dayanarak daha çok seçmen-parti karşılaştırmalarına imkân veren sonuçlar ortaya çıkarmaktadır.

Uzman anketi, diğer yöntemlerin aksine özellikle hedef kitleye ulaşılması ve zaman yönetimi açısından daha uygulanabilirdir. Marks, Wilson ve Ray (2002, s. 588), uzman anketi için 8-10 örneklemin yeterli olacağını belirtmektedir. Laver (1998, s. 337) ise ideoloji, kimlik siyaseti ve AB ile ilgili uzmanlıklarından dolayı, siyasi bilimlerin ilgili konularında çalışan akademisyenleri "uzman" olarak tanımlamakta ve önermektedir. Amaçlı örneklemin kullanılabileceği bu veri toplama tekniği için başta üniversiteler olmak üzere, ülkedeki ilgili sivil toplum kuruluşları ve araştırma merkezleri ile temasa geçilebilir.

Parti dokümanları, parti pozisyonlarının altında yatan nedenlerin derinlemesine incelenmesine imkân sağlaması bakımından, analizler için zengin bulgu ve sonuçlar ortaya çıkarmaktadır. Parti programları, seçim beyannameleri, parti sitelerinde yer alan açıklamalar, meclis tutanakları ve basın demeçleri ile mülakatlar bir bütün olarak bu teknik için kullanılabilir. Bununla birlikte bu teknikte dil bariyeri, belge içeriklerinin parti pozisyonlarını ve politikalarını ne oranda yansıttığı ve belgelerin sübjektif yorumlanması gibi engeller ve sınırlılıklar karşımıza çıkmaktadır. Araştırmacıların ülke dilini yeterli düzeyde bilmeleri beklenmekle beraber, üzerinde titizlikle çalışılmış ve kontrolleri sağlanmış tercümeler üzerinden analizlerin yapılması da mümkündür.

İçerik çözümlemesi, bir bütün olarak sübjektif yorum riskini içerisinde barındırmaktadır. İncelemenin geçerlilik ve güvenirliğini arttırmak amacıyla analizin farklı bir zaman diliminde tekrarlanması ya da ikinci bir kişi tarafından tekrarlanıp sonuçların mukayese edilmesi yöntemleri takip edilebilir (Gökçe, 2001). Ayrıca içerik çözümlemesi için akademik yazımda kabul gören, sayısal sonuçlar çıkaran bazı yazılım programları da kullanılabilir. Partilerin yazılı belge ve açıklamalarında siyaseten doğru (politically correct) bir üslup geliştirmeleri, ihtimal dâhilindedir. $\mathrm{Bu}$ durumda, uzman görüşleri ve $\mathrm{AB}$ reformlarına ilişkin parlamentodaki oy davranışları dikkate alınmalıdır. 
Partiye mensup milletvekilleri ile mülakat son yöntem olarak düşünülebilir. Fakat bu yöntemde de vekillere erişebilirlik sorunu ortaya çıkmaktadır. Bu noktada parti merkezinde çalışan ve parti dinamiklerine haiz görevliler ile alternatif olarak yerel yöneticiler ya da teşkilat mensupları (kadın ve gençlik, medya-iletişim vs. örgütlenmeleri) B planı olarak kurgulanabilir. Mülakatların analizinde ise parti içi demokrasi, parti kimliği, varsa parti-içi hizipleşmeler, liderin rol ve önemi gibi iç dinamikler dikkate alınmalıdır.

Tek ülkenin örnek olay olarak incelendiği çalışmalarda iki ayrı veri toplama tekniğinin kullanılması, derinlemesine analize imkân sağlayacak, aynı zamanda bulgu ve sonuçların geçerlilik ve güvenirliğin arttıracaktır. Çoklu ülke incelemesine dayanan çalışmalar, üç model ve alt kategoriler üzerinden parti grupları ve ülkeler arasında mukayeseler (karşılaştırmalı siyaset) yapılmasına imkân vererek literatüre katkılar sağlayacaktır.

\section{Sonuç}

Avrupalılaşma sürecinde iç politikada önemli rol oynayan hükümet ve bürokrasi, ulusal meclisler, yarg1 ve sivil toplumdan oluşan elit grupların yanı sıra siyasi partiler de bulunmaktadır. Avrupalılaşma, meclis gündemine gelen $\mathrm{AB}$ uyum paketleri üzerinden şekillenmekte ve devamında yürütmenin reformları hayata geçirme iradesine dayanmaktadır. Bu nedenle aday ülke ile $\mathrm{AB}$ arasındaki ilişkilerin açıklanabilmesi için siyasi partilerin özel bir analize tabi tutulmaları gerekmektedir.

$\mathrm{Bu}$ nedenle çalışma, $\mathrm{AB}$ gündemine ilişkin parti pozisyonlarını sorunsallaştıracak araştırmacılar için bir çerçeve sunarak Türkçe literatüre katkı sağlamayı amaçlamıştır. Bu kapsamda makale, $\mathrm{AB}$ gündemine ilişkin siyasi parti pozisyonlarına, diğer bir ifade ile takındıkları tutuma ilişkin nedensel bir açılama getirecek kuramsal ve metodolojik bir çerçeve sunmaktadır. Bu çerçevede makale, parti politikalarını oluşturan ana dinamikleri "ideoloji", "siyasi rekabet" ve "kimlik siyaseti" üzerinden değerlendirerek partilerin AB taraftarlığ1 veya (sert ya da yumuşak) AB karşıtlı̆̆ konusunda sekiz hipotez önermektedir.

"İdeoloji" modeli partilerin AB'nin desteklediği liberal ekonomiyi değerlendirmesine, ulusal egemenlik ve bağımsızlık konularında $\mathrm{AB}^{\prime}$ yi içişlerine karışan bir mekanizma olarak görüp görmemesine ve AB'nin sosyal politikalarına sıcak bakıp bakmamasına bağlı olarak sağ ve sol cenahta kutuplaşan siyasi partiler üzerine üç alternatif hipotez ortaya çıarmıştır. Ayrıca merkezdeki ılımlı partilerle aşırı uçtaki partiler arasında da AB gündemine ilişkin pozisyon konusunda ayrı bir hipotez oluşmuştur. "Siyasi rekabet" modeli incelendiğinde hükümeti oluşturan partiler ile muhalefeti oluşturan partilerin karşıt pozisyonlara sahip olabilecekleri, siyasi partilerin seçmenlerin $A B^{\prime}$ ye karşı tutumlarından etkilendikleri, ana akım partilerin protestocu partilere göre daha $\mathrm{AB}$ yanlısı olduğu konusunda üç hipotez ortaya çıkmıştır. "Kimlik siyaseti" modeli dikkate alındığında ise çok kültürlü partilerin katı milliyetçi partilere; merkezde konumlanan partilerin çevre partilere; azınlık partilerinin ise çoğunluk partilerine göre $\mathrm{AB}^{\prime}$ ye daha sıcak bakabilecekleri yönünde üç hipotez oluşturulmuştur.

Özellikle siyasi ve iktisadi geçiş sürecinde ve toplumsal dönüşüm aşamasında olan ülkelerde, $\mathrm{AB}$ gündemine ilişkin parti pozisyonlarında değişimler yaşanabilmektedir. $\mathrm{Bu}$ pozisyon değişimlerinin incelenmesinde ortaya koyduğumuz bu hipotezlerin tümünden veya bazılarından yararlanmak da mümkündür. 


\section{Kaynakça}

Adams, J., Ezrow, L., \& Somer-Topcu, Z. (2011). Is anybody listening? Evidence that voters do not respond to European parties' policy statements during elections. American Journal of Political Science, 55(2), 370-382.

Arısoy, A., \& Gül, H. (2011). Avrupa siyasi partilerinin “Avrupalılaşması". Yönetim Bilimleri Dergisi, 9(1), 179-197.

Avrupa Birliği Bakanlığı. (Şubat 2011). 22 Haziran 1993 Avrupa Birliği Konseyi Kopenhag zirvesi sonuç bildirgesi. http://www.ab.gov.tr/index.php?p=302\& adresinden 05.04.2019 tarihinde alınmıştır.

Billig, M. (1984). Political ideology: Social psychological aspects. H. Tajfel (Ed.), The social dimension içinde (s.446-470). Cambridge: Cambridge University Press.

Billig, M. (1995). Banal nationalism. London: Sage.

Bölükbaşı, H. T., Ertugal, E., \& Özçürümez, S. (2011). Avrupa entegrasyonu kuramlarıyla Türkiye'yi konu alan yazının etkileşimi: Avrupalılaşma araştırma programını Türkiye özelinde yeniden düşünmek. Uluslararası İlişkiler, 8(30), 79-82.

Börzel, T. A. (1999). Towards convergence in Europe? Institutional adaptation to Europeanization in Germany and Spain. Journal of Common Market Studies, 37(4), 573-596.

Bulmer, S., \& Lequesne, C. (2002). New perspectives on EU-member state relationships. Questions de Recherche/Research Questions, Centre d'études et de Recherches Internationales, 4, 1-35.

Checkel, J. T. (1999). Social construction and integration. Journal of European Public Policy, 6(4), 545560.

De Vries, C. E. vd. (2011). Individual and contextual variation in EU issue voting: The role of political information. Electoral Studies, 30(1), 16-28.

De Vries, C. E. (2010). “EU issue voting: Asset or liability? How European integration affects parties' electoral fortunes. European Union Politics, 11(1), 89-117.

Dechezelles, S., \& Perottino, M. (2008). Right wing populist parties and their effect on national identity politics under the conditions of Europeanization. ECPR Workshop: Is Populism a SideEffect of the Europeanization of Political Competition? Rennes.

Descartes, R. (1991). The principles of philosophy. V. R. Miller vd. (çev.). Boston: Kluwer Academic Publisher.

Diez, T. (2005). Constructing the self and changing others: Reconsidering normative power Europe. Millennium-Journal of International Studies, 33(3), 613-636.

Downs, A. (1957). An economic theory of political action in a democracy. The Journal of Political Economy, 65(2), 135-150.

Elias, A. (2009). Minority nationalist parties and European integration: A comparative study. London: Routledge.

Elster, J. (1993). Political psychology. Cambridge: Cambridge University Press.

Gökçe, O. (2001). İçerik çözümlemesi: Teori-metod-uygulama. Konya: Selçuk Üniversitesi Yayınları.

Grabbe, H. (2002). European Union conditionality and the acquis communautaire. International Political Science Review, 23(3), 249-268.

Green-Pedersen, C., \& Walgrave, S. (2014). Agenda setting, policies, and political systems: A comparative approach. Chicago: University of Chicago Press.

Haas, E. B. (1958). The uniting of Europe: Political, social, and economic forces, 1950-1957. Stanford: Stanford University Press.

Habermas, J. (2001). Justifications and application: Remarks on discourse ethics. C. P. Cronin (çev.) Cambridge: MIT Press.

Heath, A. F., Jowell, R. M., \& Curtice, J. K. (2001). The rise of new labour: Party policies and voter choices. Oxford: Oxford University Press. 
Helbling, M., Höglinger, D., \& Wüest, B. (2008). How political parties frame the European integration process. The Annual Meeting of the Swiss Political Science Association, University of St. Gallen, St. Gallen.

Heywood, A. (2012). Political ideologies: An introduction. London: Palgrave Macmillan.

Hix, S., \& Goetz, K. H. (2000). Introduction: European integration and national political systems. West European Politics, 23(4), 1-26.

Hix, S., \& Lord, C. (1997). Political parties in the European Union. New York: St. Martin's Press.

Hooghe, L., \& Marks, G. (2009). A postfunctionalist theory of European integration: From permissive consensus to constraining dissensus. British Journal of Political Science, 39(1), 1-23.

Huber, J., \& Inglehart, R. (1995). Expert interpretations of party space and party locations in 42 societies. Party Politics, 1(1), 73-111.

Hume, D. (2003). A treatise of human natüre. New York: Dover Publications.

Hutcheson, F. (1726). An inquiry into the original of our ideas of beauty and virtue. London: J. and J. Knapton.

Keating, M. (2004). European integration and the nationalities question. Politics E Society, 32(3), 367-388.

Keulman, K., \& Koós, A. K. (2014). European identity: Its feasibility and desirability. Maryland: Lexington Books.

Kopecký, P., \& Mudde, C. (2002). The two sides of euroscepticism party positions on European integration in East Central Europe. European Union Politics, 3(3), 297-326.

Laver, M., \& Hunt, B. W. (1992). Policy and party competition. New York: Routledge.

Laver, M. (1998). Party policy in Britain 1997: Results from an expert survey. Political Studies, 46(2), 336-347.

Lewis, P., \& Mansfeldová, Z. (2006). The European Union and party politics in Central and Eastern Europe. New York: Springer.

Lipset, S. M., \& Rokkan, S. (1967). Party systems and voter alignments: Cross-national perspectives. New York: Free Press.

March, J. G., \& Olsen, J. P. (1998). The institutional dynamics of international political orders. International Organization, 52(4), 943-969.

Marks, G., \& Steenbergen, M. (2002). Understanding political contestation in the European Union. Comparative Political Studies, 35(8), 879-892.

Marks, G., \& Wilson, C. J. (2000). The past in the present: A cleavage theory of party response to European integration. British Journal of Political Science, 30(3), 433-459.

Marks, G., Wilson, C. J., \& Ray, L. (2002). National political parties and European integration. American Journal of Political Science, 46(3), 585-594.

Martin, J. L., \& Matthew, D. (2010). Political position and social knowledge. Sociological Forum, 25(1), 1-26.

Miller, D. (1995). On nationality. Oxford: Clarendon Press.

Mjoset, L. (1997). Historical meanings of Europeanisation. ARENA Working Paper, 24, 1-43.

Neumayer, L. (2008). Euroscepticism as a political label: The use of European Union issues in political competition in the new member states. European Journal of Political Research, 47(2), 135160.

Olsen, J. P. (2002). The many faces of Europeanization. Journal of Common Market Studies, 40(5), 921952.

Öner, S. (2014). Avrupa'da yükselen aşırı sağ, yeni 'öteki'ler ve Türkiye'nin AB üyeliği. Ankara Avrupa Çalışmaları Dergisi, 13(1), 163-184.

Pisciotta, B. (2016). The center-periphery cleavage revisited: East and Central Europe from postcommunism to euroscepticism. Nationalism and Ethnic Politics, 22(2), 193-219. 
Pollack, M. A. (1996). The new institutionalism and EU governance: The promise and limits of institutionalist analysis. Governance, 9(4), 437-438.

Radaelli, C. M. (2003). The Europeanization of public policy. K. Featherstone and C. M.

Radaelli (Eds.), The politics of Europeanization içinde (s. 27-56). Oxford: Oxford University Press.

Rawls, J. (2009). A theory of justice. Cambridge: Harvard University Press.

Ray, L. (1999). Measuring party orientations towards European integration: Results from an expert survey. European Journal of Political Research, 36(2), 283-306.

Real-Dato, J., Lengyel, G., \& Göncz, B. (2012). National elites' preferences on the

Europeanization of policy-making. H. Best, G. Lengyel, \& L. Verzichelli (Eds), The Europe of elites: A study into the Europeanness of Europe's economic and political elites içinde (s. 67-93). Oxford: Oxford University Press.

Cowles, M. G., Caporaso, J., \& Risse, T. (2001). Transforming Europe: Europeanisation and domestic change. New York: Cornell University Press.

Schimmelfennig, F., \& Scholtz, H. (2008). EU democracy promotion in the European neighbourhood political conditionality, economic development and transnational Exchange. European Union Politics, 9(2), 187-215.

Schimmelfennig, F., \& Sedelmeier, U. (2004). Governance by conditionality: EU rule transfer to the candidate countries of Central and Eastern Europe. Journal of European Public Policy, 11(4), 661679.

Sitter, N. (2001). The politics of opposition and European integration in Scandinavia: Is euroscepticism a government opposition dynamic? West European Politics, 24(4), 22-39.

Sjursen, H. (2002). Why expand? The question of legitimacy and justification in the EU's enlargement policy? Journal of Common Market Studies, 40(3), 496-499.

Smith, A. D. (1991). Towards a global culture? M. Featherstone (Ed.), Global culture: Nationalism, globalization and modernity içinde (s.171-192). London: SAGE Publications.

Sniderman, P. M., Brody, R. A., \& Tetlock, P. E. (1993). Reasoning and choice: Explorations in political psychology. Cambridge: Cambridge University Press.

Sousa, M. M. (2006). The domestic turn in Europeanization studies: Elite perceptions of Europe. The ECPR Joint Sessions Workshop at Nicosia, Nicosia.

Szczerbiak, A., \& Taggart, P. A. (2000). Opposing Europe: Party systems and opposition to the Union, the Euro and Europeanisation. SEI Working Paper, 36, 1-16.

Taggart, P. (1998). A touchstone of dissent: Euroscepticism in contemporary western European party systems. European Journal of Political Research, 33(3), 363-388.

Tajfel, H., \& Turner, J. C. (1979). An integrative theory of intergroup conflict. The Social Psychology of Intergroup Relations, 33(47), 33-47.

Tezcan, E., \& Aras, İ. (2015). Adalet ve Kalkınma Partisi'nde Euroseptisizm: Avrupa Birliği desteğinin eleştiriye dönüşümü. Uluslararası Hukuk ve Politika, 11(41), 1-35.

Van Der Brug, W., Fennema, M., \& Tillie, J. (2000). Anti-immigrant parties in Europe: Ideological or protest vote? European Journal of Political Research, 37(1), 77-102.

Weltman, D., \& Billig, M. (2001). The political psychology of contemporary anti-politics: A discursive approach to the end-of-ideology era. Political Psychology, 22(2), 367-382.

Yazgan, H. (2012). Bir kavramsal çerçeve olarak "Avrupalılaşma": Kapsam, gereklilik ve sinırlar. Anadolu Üniversitesi Sosyal Bilimler Dergisi, 12(4), 123-140.

Yıldırım, Y. (2017). Liberal demokrasinin krizi bağlamında Avrupa'da sağ-popülizm ve yükselen aşırı-sağ. Amme İdaresi Dergisi, 50(2), 51-72. 